August 1, 2000

\title{
Troubled Banks, Impaired Foreign Direct Investment: The Role of Relative Access to Credit
}

\author{
Michael W. Klein \\ Joe Peek \\ and \\ Eric Rosengren*
}

\begin{abstract}
The relative wealth hypothesis of Froot and Stein (1991), motivated by the aggregate correlation between real exchange rates and foreign direct investment (FDI) observed in the 1980s, cannot explain one of the major shifts in FDI in the 1990s: the continued decline in Japanese FDI during a period of stable stock prices and a rapidly appreciating yen. However, when the relative wealth hypothesis is supplemented with the relative access to credit hypothesis proposed in this study, we are able to show that unequal access to credit by Japanese firms can explain the FDI puzzle in the 1990s. We utilize a unique data set that links individual Japanese firms engaged in FDI to their main banks. Using both bank-level and firm-level data sets, we find that financial difficulties at banks were economically and statistically important in reducing the number of FDI projects by Japanese firms into the United States, even after controlling for the effects associated with the relative wealth movements driven by macroeconomic fluctuations in the exchange rate and stock market prices. This provides strong empirical evidence that differences across firms in the degree of their access to credit can be an important determinant of foreign direct investment.
\end{abstract}

*M. Klein: Fletcher School of Law and Diplomacy, Tufts University, Medford, MA 02155, (617) 627-2718, fax: (617) 627-3712, and N.B.E.R., mklein@tufts.edu;

J. Peek: Gatton College of Business and Economics, University of Kentucky, Lexington, KY 40506-0034, (859) 257-7342, fax: (859) 257-9688, Jpeek0@ pop.uky.edu;

E. Rosengren: Research Department, T-8, Federal Reserve Bank of Boston, 600 Atlantic Avenue, Boston, MA 02106, (617) 973-3090, fax: (617) 973-2123, Eric.Rosengren@ bos.frb.org

We thank Steven Fay and Zarmeen Katchi for providing valuable research assistance. The authors have benefited from the comments of Randall Morck and Chris James, as well as participants in the NBER Universities' Research Conference and Japan Project workshop. The views expressed are those of the authors, and do not necessarily reflect official positions of the Federal Reserve Bank of Boston or the Federal Reserve System. 


\section{Troubled Banks, Impaired Foreign Direct Investment: The Role of Relative Access to Credit}

For many years, most theories of the determination of foreign direct investment (FDI) focused on industrial organization motives. While these traditional models of FDI could explain industry-specific patterns, these models alone were not sufficient to explain the striking correlation between real exchange rates and FDI that developed during the 1980s. Foreign direct investment into the United States surged in the wake of the steep dollar depreciation beginning in late 1985. To explain this correlation, the FDI literature was expanded to include the role of imperfect capital markets in describing the pattern of movements in FDI among industrial countries. In particular, a key contribution provided by Froot and Stein (1991) is a parsimonious model based on informational imperfections that generates a link between economywide FDI and aggregate variables, such as the real exchange rate. A depreciation of the domestic currency increases the relative wealth of foreign firms, enabling them to outbid domestic firms in acquiring corporate assets. Froot and Stein provide empirical evidence that aggregate FDI into the United States is related to fluctuations in the real exchange rate.

Just as events in the 1980s indicated a need for richer explanations than could be provided solely by industrial organization models, events in the 1990s motivate relaxing one of the assumptions underlying the Froot and Stein model, that of equal access by all firms to external borrowing facilities. The relative wealth hypothesis cannot fully explain one of the most dramatic swings in FDI during the 1990s, the collapse of outward direct investment by Japan, one of the primary sources of FDI, particularly for the United States and Asia. Japanese FDI as a share of total FDI into the United States reached a peak of 30 percent in 1990, and then declined through much of the 1990s, falling to only 1 percent of total FDI into the United States 
by 1998. While the relative wealth hypothesis can explain the dramatic increase in Japanese outward FDI during the 1980s, as well as the initial decline after the Japanese asset-price bubble burst, it does not explain why Japanese FDI continued to decline even as the Nikkei stabilized and the yen appreciated significantly during the mid 1990s.

An additional hypothesis proposed in this paper also highlights imperfect capital markets, but it focuses on the constraints faced by bank-dependent firms when their lenders reduce credit availability. This hypothesis, in conjunction with the relative wealth hypothesis, provides an explanation consistent with the more recent Japanese FDI experience. While firms may be constrained by their balance sheet positions, they may also be constrained by a reduction in the willingness of lenders to provide credit, in particular, by an inward shift in loan supply caused by a deterioration in bank health. This relative access to credit hypothesis (RAC) implies that firms' ability to engage in foreign direct investment will be influenced by their ability to raise external funds. Thus, RAC can explain the continuing collapse in Japanese FDI by focusing on one of the most striking aspects of the Japanese economy in the 1990s, the collapse of its banking sector. Not only can RAC explain the continued reduction in FDI despite a substantial appreciation in the real value of the yen, but it also provides a richer set of implications at the micro firm level: Individual firms associated with less healthy banks should be less likely to engage in FDI.

The environment and events in Japan provide a "natural experiment" that allows empirical tests that can distinguish RAC from the relative wealth hypothesis. First, because of the importance of the main bank system, many Japanese firms rely heavily on bank finance. Second, Japan experienced a dramatic collapse in the financial condition of its banking system in the early 1990s. Third, suitable data are available to construct a unique data set that links 
individual firms engaged in FDI to their main bank, so that hypotheses can be tested on bankand firm-level data. Finally, the unusually large shifts in Japanese stock prices, exchange rates, and bank health experienced over the past two decades are not perfectly coincident, providing a natural experiment suitable for testing alternative hypotheses about the determinants of FDI.

We find strong support for RAC, since financial difficulties at Japanese banks are economically and statistically important determinants of Japanese FDI into the United States, even after controlling for the relative wealth movements caused by fluctuations in stock prices and exchange rates. In fact, we find that a single Moody's downgrade of a Japanese bank on average results in a decline of about one-third in the number of FDI projects into the United States by Japanese firms that use that bank as their main bank. With foreign-owned firms accounting for 5 percent of all U.S. employment and 6 percent of goods and services produced here (Zeile 1999), major declines in their participation in the U.S. economy can have significant long-run effects, even though the U.S. economy is relatively large and insular. The effects of the collapse of Japanese direct investment in other countries, especially those in East Asia that are more dependent on Japanese direct investment, are potentially far more dire.

The next section of this paper provides some background on FDI. The second section describes our data set and offers some initial statistics on the health of Japanese banks, as measured by Moody's ratings, as well as on FDI by Japanese firms. Section III describes our empirical test of the relative access to credit hypothesis and the evidence supporting the hypothesis, using bank-level data formed by aggregating all FDI projects by firms using a particular main bank. Section IV provides further empirical evidence documenting the link between bank health and FDI using a panel logit regression specification with firm-level data for those firms engaged in FDI. The final section offers some concluding remarks. 


\section{Background}

To determine why a foreign firm would value domestic assets more highly than a domestic firm would, much of the literature has focused on synergies generated by managerial advantages, superior marketing ability, or technological advantages, as summarized, for example, in Caves (1971) and Graham and Krugman (1995). Given the focus on direct investment flows from developed to less developed countries, the literature tended to emphasize relative labor costs (Cushman 1987) and policy influences on FDI through fiscal powers, such as tax incentives (Slemrod 1989; Swenson 1994).

None of these earlier papers provided a theoretical justification for the correlation between aggregate FDI and real exchange rates for industrial countries. However, by the early 1990s, the observed strong correlation between the surge of FDI into the United States and the depreciation of the dollar suggested that new theoretical extensions to the standard theory were required. Froot and Stein (1991), by relaxing the assumption of perfect capital markets, provided the first theoretical model that could explain this empirical observation. In their model, imperfect information about investment opportunities causes lenders to impose leverage requirements on borrowers. They reasoned that FDI could be modeled as an auction for assets between foreign and domestic firms. An increase in the wealth of foreign bidders relative to domestic bidders, for example through a depreciation in the value of the domestic currency, would allow foreign firms to bid more aggressively for domestic assets. Froot and Stein (1991) were able to generate their results from a stylized model that assumed that all firms have equal access to credit markets, and thus they were able to obtain their results without having to rely on another important dimension of imperfect capital markets: the fact that the availability of external finance varies across firms and across time. 
Froot and Stein (1991) also provide empirical support for their relative wealth hypothesis using aggregate inward FDI and multilateral real exchange rate data. While this test is consistent with the observed correlation that motivated their theory, it utilizes a narrow definition of changes in relative wealth. A broader test of the relative wealth hypothesis was provided by Klein and Rosengren (1994). They use panel data for a set of seven countries that provide additional support for the relative wealth hypothesis, finding that both bilateral real exchange rates and a measure of relative stock market wealth contribute to the explanation of FDI into the United States.

Nonetheless, developments in the 1990s provided an anomaly with respect to movements in FDI not easily explained by the relative wealth hypothesis. Figure 1 shows the proportion of Japanese FDI in total inward U.S. FDI, measured by value (solid line) and by number of projects (dashed line), along with a measure of the relative exchange rate for Japan (dotted line). The relative exchange rate is calculated as the real trade-weighted exchange rate of the dollar divided by the real yen/dollar exchange rate. The relative exchange rate series in the figure has been lagged one year, since FDI likely does not react instantaneously to changes in the real exchange rate. The real relative exchange rate and the two measures of the proportion of Japanese FDI in total inward FDI, at least until 1991, exhibit the strong positive correlation that motivated the Froot and Stein (1991) study. ${ }^{1}$ As the relative values of the yen and the Japanese stock market each rose during the 1980s, so did the Japanese share of inward U.S. FDI. Similarly, both measures of Japanese FDI fell as the asset-price bubble burst and as the relative value of the yen declined at the turn of the decade. After 1991, however, the correlation changes. While the Nikkei stabilized, the value of the yen rose dramatically in the early to mid 1990s, yet the Japanese proportion of the number of FDI projects remained flat, beginning in 1993, and the 
Japanese proportion of the value of FDI continued to decline, with the exception of a temporary rise in 1996.

The failure of Japanese FDI into the United States to increase with the large appreciation in the yen in the early to mid 1990s cannot be explained by the relative wealth hypothesis. However, we argue that this puzzle can be explained by relaxing an assumption underlying the Froot and Stein model: equal access to credit markets by all firms. This period of low participation in FDI into the United States by Japanese firms corresponds with the period of increasingly severe financial difficulties experienced by Japanese banks. The low proportion of Japanese FDI into the United States in the 1990s, despite a period of substantial yen appreciation, can be explained by Japanese firms having relatively limited access to credit, as the financial positions of Japanese banks deteriorated and as Japanese government enforcement of banking regulations became more stringent.

The relative access to credit hypothesis (RAC) implies that firms' ability to engage in foreign direct investment will be influenced by their ability to raise external funds. If firms are highly dependent on obtaining funds from banks with which they have a historical relationship, then the ability to finance foreign investments will depend, in part, on the financial condition of their bank. The consequences of the deterioration in the balance sheets of the financial intermediaries that provide credit to the firms, as well as the deterioration in the balance sheets of the firms themselves, are consistent with a large and growing literature on the importance of bank financing for firm investment (Fazzari, Hubbard, and Petersen 1988; Gertler and Gilchrist 1994; Kashyap, Stein, and Wilcox 1993; Kashyap, Lamont, and Stein 1994). While bankborrower relationships have been found to be important in the United States (Petersen and Rajan 
1994), such links are likely to be even more important in a country that is far more reliant on bank financing, such as Japan.

Banking problems in Japan are likely to be especially important influences on firms' investment decisions, particularly for investment abroad. First, bank-firm lending relationships are quite strong and important in Japan (Hoshi, Kashyap, and Scharfstein 1990, 1991; Hoshi, Scharfstein, and Singleton 1993; Hall and Weinstein 1997). Banks frequently have both debt and equity positions in their large borrowers, borrowers are frequently stockholders of the bank, and bankers often sit on the board of large or troubled borrowers (Morck and Nakamura 1999). Second, Japanese banks increasingly have focused on lending for domestic purposes (Peek and Rosengren 1997, 2000), both because of banking regulations that forced banks to shrink and because the government used moral suasion to encourage domestic lending to avoid a credit crunch. Third, while the Japanese bond market has begun to develop (Hoshi and Kashyap 2000), bank lending remains a very important source of debt financing, even for relatively large firms. Finally, the Japanese banking crisis has been of global significance, as virtually all the major Japanese banks have required substantial capital infusions from the government and continue to be handicapped by severe loan loss problems. Thus, RAC is consistent with the persistent decline in Japanese FDI associated with the sharp deterioration in the health of the banking sector, which caused Japanese banks to reduce the supply of credit to Japanese firms and made it more difficult for these firms to finance FDI projects.

\section{The Data}

The focus of our study is the possible link between foreign direct investment in the United States by Japanese firms and the health of the respective firms' main banks in Japan. We 
are able to analyze this question with a new data set that includes time series of the number of FDI projects by individual Japanese firms and identifies each firm's main bank. This data set enables us to isolate the role of the relative health of individual banks and to distinguish the relative access to credit hypothesis from other possible reasons for the decline in Japanese FDI in the 1990s.

We use firm-level direct foreign investment data from the United States International Trade Administration (ITA). The ITA provides a transactions roster of all publicly disclosed investments that identifies the investing company, the SIC code of the target company, and, when made publicly available (about half of all cases), the value of the acquisition. ${ }^{2}$ The data begin in 1987 and end in 1994, when the ITA stopped collecting direct investment data on a bilateral basis.

We identify the industry and the primary bank for each firm in our data set using information from the Japan Company Handbook $(\mathrm{JCH})$. The main (primary) bank is the first bank listed among reference banks for each firm. ${ }^{3}$ We focus on firms associated with one of the 11 banks that had at least one firm with a main bank relationship engaged in FDI in each year. The 11 banks in our sample are the Industrial Bank of Japan (IBJ), Sakura Bank, Fuji Bank, Mitsubishi Bank, Sanwa Bank, Asahi Bank, Tokai Bank, Sumitomo Bank, Long-Term Credit Bank (LTCB), Daiwa Bank, and Dai-Ichi Kangyo Bank (DKB). ${ }^{4}$ With the exception of IBJ and LTCB, which were the largest of Japan's long-term credit banks during our sample period, all of the banks were among the largest city banks in terms of total assets.

Table 1 shows the number of FDI projects by Japanese firms grouped by the firm's main bank. For each bank and each year, we include the total number of FDI projects by firms associated with that bank. The pattern of FDI across the banks indicates robust FDI through the 
late 1980s, generally peaking in 1989 , and then declining to much lower levels for the early 1990s.

The timing of the general decline in FDI corresponds with the collapse of the Japanese banking sector. However, by looking at the relative timing and magnitudes of the deterioration in the financial health at individual banks, we can exploit the information that reflects heterogeneity across banks, as opposed to only that reflecting the overall weakness of the Japanese banking sector. One simple indicator that can be used to gauge the relative changes in financial conditions across Japanese banks is the time series of rating downgrades for individual banks. ${ }^{5}$ For the $1986-94$ period, Table 2 presents the year-end values for Moody's long-term deposit ratings for the 11 Japanese banks that were the most active lenders to Japanese firms engaged in FDI into the United States. Each of the banks that had a Moody's long-term deposit rating in 1986 enjoyed the highest rating, Aaa. From that point on, however, the fortunes of these banks diverged. Although only three banks experienced rating downgrades prior to 1990, a wave of downgrades occurred in 1990. Ratings dropped by one level for DKB, Mitsubishi Bank, Fuji Bank, Sumitomo Bank, and Tokai Bank, and by two levels for LTCB. In subsequent years, downgrades affected each bank in this sample, with five banks downgraded in 1991 (with three of those banks dropping by two levels), six banks downgraded in 1992 (three dropping by two levels), seven banks downgraded in 1993 (Daiwa by three levels), and one bank downgraded in 1994. From 1990 through 1994, one bank was downgraded by four levels, four banks were downgraded three levels, and six banks were downgraded two levels. In addition, there are substantial cross-sectional differences in bank health, with a two- to four-level difference between the healthiest and weakest banks in each year after 1986. 
We have constructed a new data set that contains a comprehensive list of publicly available data on FDI into the United States by the 445 Japanese firms during the period 1987 to 1994 for which we can identify the main bank. The cross-sectional and time series variations in these data enable us to isolate the effect of bank health on direct foreign investment, while controlling for aggregate and firm-specific factors that affect FDI. We use these data to perform two sets of empirical tests. First, we test the relative access to credit hypothesis (RAC) using a bank-level data set formed by aggregating the firm-level data, combining FDI projects for all firms that use the same main bank. We use these data to investigate the determinants of the change in the number of FDI projects of firms associated with a specific main bank. Second, we test RAC using a logit specification with the firm-level data, in order to investigate the determinants of the probability that a firm will undertake FDI in a given year.

Another benefit provided by this new data set for testing the relative access to credit hypothesis is its potential ability to overcome the common difficulty in the literature of isolating loan supply shocks from shocks to loan demand, since bank financing problems in Japan are not coincident with declines in the demand for investments in the United States. Identification of financial constraints affecting a firm's investment decisions has been problematic, with much of the evidence indirect and not relying on firm-level data that connect the firm to its sources of financing. Furthermore, identifying the role of disruptions in bank financing is often difficult because one cannot distinguish convincingly between loan supply and loan demand shocks. For example, the deterioration of banks' balance sheets and firms' prospects may occur contemporaneously, so that the data may not permit unambiguous identification of the source of a reduction in investment. 


\section{Methodology and Empirical Results - Bank-Level Data}

The empirical test using bank-level data examines the extent to which the declines in FDI occur disproportionately at firms whose banks suffered the greatest financial difficulties. While

all major Japanese banks experienced some difficulties during the early 1990s, the timing and the degree of the deterioration in their financial health varied across banks. The most troubled banks would be expected to restrict lending most dramatically to their customers. Thus, other things equal, it is the firms that rely on the most troubled banks that would be most limited in their ability to obtain debt financing for expansion abroad.

To capture this effect, we estimate the following equation:

$$
D F D I_{i, t}=\alpha_{0}+\alpha_{1} \text { DRATING }_{i, t-1}+\alpha_{2} \text { DPROFIT }_{i, t-1}+\alpha_{3} \text { DMACRO }_{t-1}+\varepsilon_{i, t} .
$$

The dependent variable, $\mathrm{DFDI}_{\mathrm{i}, \mathrm{t}}$, is obtained by first collapsing the firm-level data set, in which each observation represents the number of direct investment projects by an individual firm in a particular year, into a data set in which we count the number of investment projects by all firms associated with a particular main bank in a given year. DFDI is the percentage change between year $t-1$ and year $t$ in the number of FDI projects by firms that use bank $i$ as their main bank. $^{6}$ DRATING $_{\mathrm{i}, \mathrm{t}-1}$ is a measure of changes (downgrades) of Moody's long-term deposit rating for the individual Japanese banks during the prior year. The measure of Moody's downgrades uses two separate $(0,1)$ dummy variables. Single Downgrade has a value of one if the bank's rating is downgraded one level in a given year and zero otherwise. Multiple Downgrades has a value of one if the bank is downgraded two or more levels in a given year and zero otherwise. ${ }^{7}$ Thus, while the deterioration in the financial condition of all banks may have influenced FDI into the United States by Japanese firms, this specification will allow us to exploit the cross-sectional 
variation in the timing and degree of the deterioration of Japanese bank health. By focusing on cross-sectional differences in bank health rather than on the macroeconomic variables that have been the focus of much of the recent work on FDI (Froot and Stein 1991; Klein and Rosengren 1994), we can identify an additional determinant of Japanese FDI that may have been an important factor in its decline in the 1990s, the effects of loan supply shocks.

The variable DPROFIT is intended to control for the weakening of the health of firms that engage in FDI. If the weakening of the FDI firms contributed to the deterioration in bank health, this weakening could serve as the cause of the declines in both bank health and FDI. Consequently, we control for the average health of the FDI firms associated with each main bank. DPROFIT is based on the profitability of the set of firms associated with a particular main bank that engaged in FDI at any time during our sample period. It is calculated for each main bank as the change in the sum of profits during the prior year for the set of firms associated with each bank, scaled by the sum of their assets. ${ }^{8}$

The third vector, DMACRO, contains a set of three macroeconomic variables intended to control for differences in wealth and economic activity between Japan and the United States. These are time series variables that are not bank specific, having the same value for each bank in a given year. In each instance, they are measured over the prior year. The first variable is Relative Wealth, measured as the percentage change in the real Japanese Nikkei stock index, which has been deflated by the Japanese wholesale price index, plus the percentage change in the real (dollar/yen) exchange rate, minus the percentage change in the real U.S. S\&P 500 stock index, which has been deflated by the U.S. producer price index. The Relative Wealth variable incorporates into our specification the hypothesis suggested by Froot and Stein (1991), and tested in Klein and Rosengren (1994), that exchange rate movements and relative stock prices may be 
important in explaining movements in FDI because of capital market imperfections. Froot and Stein (1991) posit that favorable currency and stock price movements will alter the amount a firm will be able to bid for foreign assets. If so, the estimated coefficient on Relative Wealth should be positive. We also include the change in the U.S. unemployment rate and the change in the Japanese ratio of job offers to applicants, to control for the macroeconomic business cycle in each country. We estimate each equation using ordinary least squares (OLS), with robust standard errors calculated by relaxing the assumption of independence of the observations for a given year. ${ }^{9}$

Table 3 contains the results for equation 1. Japanese firms that engaged in FDI for any year during the sample period have been aggregated by their associated main bank. The regression includes observations for the 11 banks that have at least one FDI project associated with its firms in each year. Annual observations for the 1988 to 1994 period for the 11 banks provide 73 observations for the full sample. ${ }^{10}$

The first column contains the results for the Moody's rating downgrades specification with the percentage change in the number of FDI projects for the set of firms associated with a given bank as the dependent variable. The Moody's downgrade variables distinguish between single and multiple downgrades in a given year. The estimated coefficient on Single Downgrade is negative and significant, indicating that a downgrade of a bank by a single level in the prior year produces a change in the number of FDI projects by firms that use the bank as their main bank of -31.06 percent. A multiple downgrade, in all but one instance representing a two-level downgrade, causes a reduction in FDI projects that is statistically significant and slightly more than double the effect of a single downgrade, a decline of two-thirds in the number of projects undertaken by firms associated with that main bank. Thus, it appears that multiple downgrades 
in the same year increase the pressure on banks roughly proportionately, with the result that the firms associated with the bank sharply cut back the number of FDI projects.

Among the firm and macroeconomic control variables, the estimated coefficient on Relative Wealth is positive but not quite significant at the 10 percent level. The estimated coefficient on Firm Profitability is negative but not statistically significant. The estimated coefficient on the change in the U.S. unemployment rate is negative but not significant. The change in the Japanese Job Offers/Applications ratio has an estimated coefficient that is negative and significant, indicating that a weaker domestic economy encourages Japanese firms to engage in FDI into the United States.

Column 2 serves as a robustness check and as a transition to the specifications shown in columns 3 and 4 . This specification replaces the percentage change in the number of FDI projects with the proportional change for the dependent variable. This limits the range of values that the dependent variable can take on, which may become important when the number of FDI projects associated with a particular bank approaches zero. The column 2 results show that using proportional changes in place of percentage changes provides estimates for the two downgrade variable coefficients that are quite similar to those in column 1. Although the estimated coefficients are slightly smaller, their t-statistics are larger. The estimated coefficient on Relative Wealth is now much smaller and that on Firm Profitability is now positive, although not significant. The change in the U.S. unemployment rate is negative and significant, as is that on the change in the Japanese Job Offers/Applications ratio. Thus, a slowdown in economic activity in the United States would reduce inward FDI there, as would be expected, and a strengthening of economic activity in Japan would also reduce such FDI. 
The third and fourth columns examine the subsample of FDI firms that engaged in foreign direct investment in multiple years. This eliminates firms that engaged in FDI in only one year over the eight-year period. Because the latter firms engage in FDI into the United States only infrequently, they may not be as committed to actively pursuing FDI opportunities and thus may not be looking regularly for them. Including these firms in the sample may add more noise than information, insofar as their nonparticipation in FDI in any given year is unrelated to the availability of credit.

Because restricting our sample to firms engaged in FDI in multiple years reduces the number of FDI projects, in some cases to zero for a particular bank in a given year, we report only the results for the proportional change specification of the dependent variable. The use of percentage changes would force the omission of some observations for which the dependent variable is undefined and would introduce additional volatility associated with fluctuations in the number of FDI projects associated with banks, as those numbers become quite small in some years. The estimates in column 3 indicate that both Single Downgrade and Multiple Downgrades retain their significant negative estimated coefficients. Furthermore, compared to those in column 2, the estimated coefficients are now somewhat larger, about 30 percent larger for Single Downgrade and almost 50 percent larger for Multiple Downgrades. The magnitude of the estimated coefficient on Relative Wealth is virtually unchanged, although it is now significant at the 10 percent level. The estimated coefficient on Firm Profitability is now much larger and statistically significant. The two measures of macroeconomic activity retain their significance.

As an additional robustness test, the fourth column contains results for the subset of the nine banks that have the most FDI projects by firms that use them as their main bank. The two 
omitted banks, Daiwa and LTCB, have as few as one firm engaged in FDI in some years and, with the multiple-year FDI sample, the number falls to zero in some years. Omitting these two banks eliminates observations in which a few FDI projects can account for a large proportional change in the dependent variable. On the other hand, because these two banks are also the weakest banks in our sample, they may be the banks for which deteriorating health would be expected to have the largest impact on FDI.

The results in column 4 indicate that the estimated effects of the ratings downgrade variables are slightly smaller (in absolute value) when the sample is reduced to this set of nine banks. However, the estimated coefficients are still larger than those in column 2 that include the projects of all FDI firms. The estimated coefficients on both Firm Profitability and the U.S. Unemployment Rate are no longer significant, although the estimated coefficient on Relative Wealth is much larger and is now significant. The estimates in column 4 indicate that our results are robust and are not being driven by the observations associated with the two banks that are the weakest and that have the fewest FDI firms associated with them.

We interpret our evidence as indicating that the substantial decline in Japanese bank health caused Japanese firms that rely on those banks for credit to cut back on FDI projects in the United States. Because we find significant effects for the ratings downgrade variables even after controlling for relative wealth, firm profitability, and economic activity in both the United States and Japan, we conclude that our results are not due to a weakening in the health of firms engaged in FDI being correlated with, or even causing, the deterioration in bank health in Japan. Rather, the decline in FDI into the United States associated with deteriorating bank health occurred for healthy as well as unhealthy FDI firms, as the firms' main banks reduced credit availability in response to the adverse shock to the banking industry. 


\section{Methodology and Empirical Results - Firm-Level Data}

The previous section documents that Moody's downgrades of a bank have an economically large and statistically significant effect on foreign direct investment projects by firms associated with that bank. While such an analysis provides a good aggregate measure of the impact on foreign direct investment of a deterioration in bank health, the aggregation by bank makes it difficult to control for differences across firms that have the same main bank. This section addresses that issue by examining firm-level data to determine whether the probability that an individual firm engages in FDI is affected by a deterioration in bank health. Such a specification provides an alternative methodology for examining the importance of unequal access to credit for firms that engage in FDI. This specification uses firm-level data rather than bank-level data and focuses on the probability of a firm engaging in FDI, rather than on changes in the number of FDI projects. The sample of individual firms used here is the set of firms that engaged in FDI into the United States in more than one year during our sample period, the preferred sample used in the previous section.

The basic equation to be estimated is:

$$
\operatorname{Pr}\left(F D I_{i, t}\right)=\ell_{0}+\ell_{1} \operatorname{RATING}_{i, t-1}+\ell_{2} \text { FIRM }_{i, t-1}+\ell_{3} \operatorname{MACRO}_{i, t-1}+u_{i, t}
$$

The dependent variable, $\operatorname{Pr}\left(\mathrm{FDI}_{\mathrm{i}, \mathrm{t}}\right)$, is a limited dependent variable that has a value of 1 if firm $i$ engaged in at least one foreign direct investment in year $\mathrm{t}$, and 0 otherwise. RATING $_{\mathrm{i}, \mathrm{t}-1}$ is a measure of the level of Moody's long-term deposit rating for the individual Japanese bank identified as the main bank for firm $i$ in December of the prior year. The proxies for the Moody's ratings are a set of six $(0,1)$ dummy variables, one for each of the individual ratings from Aa1 through A3, with Aaa being the omitted rating. Thus, the estimated coefficients on 
these ratings dummy variables indicate the effect relative to that when the firm's main bank has a Moody's Aaa rating.

The second vector, FIRM, includes variables to control for firm size, for the firm's industry, and for changes in the health of the individual firms that engage in FDI. It is important to control for firm health, insofar as the weakening of the FDI firms may have contributed to the deterioration in bank health. If so, the weakening of FDI firms could serve as the cause of the declines in both bank health and FDI. We use two measures to control for the health of the FDI firms: Relative Wealth and Firm Profitability. The first measure is based on the stock price of the firm, measured as the market value of firm $i$ indexed to 100 in 1992, times the nominal dollar/yen exchange rate, divided by the S\&P 500 index. Our measure is constructed as the natural logarithm of this variable, measured in December of the prior year. This is similar to the relative wealth variable constructed in the previous section, except that it is constructed using the firm's individual stock price rather than the Nikkei index to measure changes in the amount a Japanese firm will be able to bid for U.S. assets. If a higher stock price and a higher value of the yen enhance the ability of the firm to bid for foreign assets, as posited by Froot and Stein (1991), the estimated coefficient on Relative Wealth should be positive. The second measure of firm health, Firm Profitability, is calculated as the profit-to-asset ratio of the firm, measured in the prior year. Again, we expect a positive coefficient. We include a variable, Firm Size, which is the logarithm of the real value of the firm's assets in the prior year, using the Japanese wholesale price index as the deflator. Because larger firms are more likely to engage in international activities and have the funding capacity to undertake foreign direct investment, we anticipate a positive coefficient. Finally, we also include a set of industry dummy variables to control for 
differences across industries in the proclivity to engage in foreign direct investment, although they are not reported in the tables in order to conserve space. ${ }^{11}$

The third vector, MACRO, contains a set of two macroeconomic variables intended to control for differences in economic activity between Japan and the United States. The U.S. unemployment rate and the Japanese job-offers-to-applicants ratio should control for the macroeconomic business cycle in each country. These are time series variables that are not firm specific, having the same value for each firm in a given year. In each instance, they are measured over the prior year. Again, we adjust estimated coefficient standard errors to account for the presence of aggregate regressors.

Table 4 shows the results of estimating the firm-level logit regressions. The first column reports estimates for the probability of a firm undertaking one or more FDI projects, using only the set of dummy variables for the level of the Moody's rating for the firm's main bank as explanatory variables. As expected, each of the estimated coefficients is negative and five of the six coefficients are statistically significant, indicating that firms associated with main banks whose ratings have declined below Aaa have a lower probability of engaging in foreign direct investment. In addition, the estimated coefficients on the two lowest ratings are much larger in absolute value than those for the highest two ratings, indicating that the more troubled the firm's main bank, the less likely the firm will undertake FDI.

The specification in the second column also includes the firm and macroeconomic control variables. With the inclusion of the additional explanatory variables, the six coefficients on the bank rating dummy variables remain negative, with three of the estimated coefficients remaining statistically significant at the 1- percent level. Again, the probability of undertaking FDI is the lowest if the firm's main bank has one of the two lowest ratings. The other explanatory variables 
are each correctly signed and statistically significant. The probability of engaging in foreign direct investment is positively related to the firm's market value measured relative to that of U.S. stocks, the firm's profitability, and the firm's size. The probability of the firm undertaking FDI is reduced if the unemployment rate in the United States is high or if the job-offers-to-applicants ratio in Japan is large.

The third column is estimated on a sample that omits firms in the auto and steel industries, the two industries most affected by the threat of U.S. trade restrictions. It is possible that firms in these two industries were forced to invest in the United States by trade barriers and that these investment patterns may be spuriously correlated with the condition of their banks. The evidence in the third column indicates that the results are not sensitive to the exclusion of firms in these two industries.

It is likely that the health of the main bank would most affect the foreign investment decisions of those firms that had few alternative sources of financing. Table 5 provides three alternative sample selections that exclude firms that are least likely to be dependent on their main bank for financing. The first column excludes those firms that are in the highest decile by total assets in one or more years during our sample period. Because of changes in the composition of the largest 10 percent of firms from year to year and because the larger firms tend to be in our sample for more years on average, excluding the largest firms in this way eliminates almost 17 percent of the sample. Column 1 shows that when the largest firms are excluded, the estimated coefficients on each of the six ratings dummy variables are negative, with five being statistically significant (including all four of the lowest ratings).

The second column excludes firms that are listed on either the New York or London stock exchanges, or both. Firms with worldwide access to equity markets are less likely to be 
dependent on their main bank to finance foreign investments. Exclusion of these firms reduces the sample by 113 observations ( 7.6 percent). Again, all six of the estimated coefficients on the ratings variables are negative, with four being statistically significant and the two lowest ratings having the largest (in absolute value) coefficients.

The third subsample excludes those firms with a ratio of outstanding bonds to total liabilities that is in the top decile for all firms in our sample. Exclusion of these firms reduces the observations in our sample by 148. Again, the estimated coefficients on all six of the ratings variables are negative, with three being statistically significant, and the two lowest ratings having by far the largest (in absolute value) coefficients.

The results for the firm-level logit specifications provide strong support for the relative access to credit hypothesis, in line with the bank-level regression results. A firm's foreign direct investment is positively associated with the financial condition of the main bank, as measured by the main bank's Moody's ratings. The results are robust to examining changes in FDI at firms associated with specific main banks or to examining levels of FDI at individual firms using a logit regression. Both sets of results are robust to alternative specifications and provide strong evidence that part of the dramatic decline in Japanese foreign direct investment into the United States during the 1990s can be attributed to the deteriorating health of Japanese banks.

\section{Conclusion}

In this paper, we propose the relative access to credit hypothesis (RAC) to explain a major puzzle in the pattern of foreign direct investment, the continued decline of Japanese foreign direct investment (FDI) into the United States in the early and mid 1990s after the Japanese stock market had stabilized and while the Japanese yen was appreciating dramatically, 
conditions under which the relative wealth hypothesis would have predicted increased Japanese FDI into the United States. Unlike the relative wealth hypothesis, which focuses on imperfect information generating imperfect capital markets, we relax the assumption that firms have equal access to credit. We show that firms' ability to raise external financing was impaired by the deteriorating financial condition of Japanese banks, so that FDI declined most for firms that were reliant on the most troubled Japanese banks. Even as the historically close ties between Japanese firms and Japanese banks are beginning to break down (Hoshi and Kashyap 2000), Japanese firms remain highly leveraged and far more dependent on bank financing than firms in the United States. Thus, many Japanese firms are still likely to have great difficulty obtaining alternative financing if their main bank is unable, or unwilling, to provide additional financing.

Not only is Japan a particularly good laboratory for exploring RAC because of the collapse of major Japanese banks in the 1990s, the particularly strong relationships between firms and banks, and the importance of outward Japanese FDI for the rest of the world, but also because data are available that enable us to construct a unique data set ideally suited for testing RAC. Unlike in the United States, firm-bank relationships can be clearly identified in Japan and annual FDI investments by particular Japanese firms are available. Evidence based both on bank-level panel data linking FDI by firms to their main bank and on a panel data set of individual firms strongly support the RAC hypothesis, indicating a statistically and economically important relationship between bank health and the ability of Japanese firms to invest in the United States.

Japanese FDI into the United States provides a particularly good test of RAC, but the RAC hypothesis should have much broader ramifications. While much of the power of our test is based on cross-sectional differences among Japanese banks, the financial condition of all 
Japanese banks deteriorated, indicating that Japanese firms were likely disadvantaged relative to U.S. and European firms operating in Asia and Europe, as well as in the United States. The Japanese have been a major source of FDI into the United States, peaking at 30 percent of all FDI in 1990, but the effects of the decline in FDI would likely be much more severe for small, newly developed countries, such as those in Southeast Asia. For those countries that are heavily dependent on foreign direct investment, particularly from Japan, this transmission mechanism indicates why these countries have been so concerned about the slow pace of recovery for Japanese banks. 
Bibliography

Blonigen, Bruce A. "Firm-Specific Assets and the Link Between Exchange Rates and Foreign Direct Investment.” The American Economic Review, June 1997, 87, pp. 447-65.

Caves, R. "International Corporations: The Industrial Economics of Foreign Investment." $\underline{\text { Economica, }}$ 1971, $\underline{38}$, pp. 1-27.

Chamberlain, G. "Analysis of Covariance with Qualitative Data." Review of Economic Studies, $1980, \underline{42}$, pp. 225-38.

Cushman, D. “The Effects of Real Wages and Labor Productivity on Foreign Direct Investment.” Southern Economic Journal, 1987, 54, pp. 174-85.

Fazzari, Steven, R.; Hubbard, Glenn and Petersen, Bruce C. "Financing Constraints and Corporate Investment." Brookings Papers on Economic Activity, 1988, (1), pp. 141-95.

Froot, K. and Stein, J. "Exchange Rates and Foreign Direct Investment: An Imperfect Capital Markets Approach.” Quarterly Journal of Economics, November 1991, 106, pp. 1191217.

Gertler, Mark and Gilchrist, Simon. "Monetary Policy, Business Cycles, and the Behavior of Small Manufacturing Firms.” Quarterly Journal of Economics, May 1994, 109, pp. $309-40$.

Gibson, Michael S. "Can Bank Health Affect Investment? Evidence from Japan.” Journal of

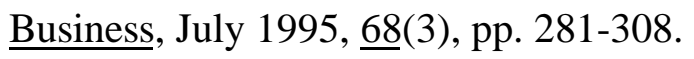

Goldberg, Linda and Michael Klein W. "FDI, Trade and Real Exchange Rate Linkages in Developing Countries," in R. Glick, ed., Managing Capital Flows and Exchange Rates: Lessons from the Pacific Basin. Cambridge, MA: Cambridge University Press, 1998, pp. 1-29. 
Graham, E. and Krugman, P. Foreign Direct Investment in the United States, Washington, DC: Institute for International Economics, January 1995. - third edition

Hall, Brian J. and Weinstein, David E. "Do Banking Relationships Reduce Corporate Myopia? Evidence from Japan.” Unpublished manuscript, April 1997.

Hoshi, Takeo and Kashyap, Anil. "The Japanese Banking Crisis: Where Did It Come From and How Will It End?" in Ben Bernanke and Julio Rotemberg, eds., NBER Macroeconomics Annual 1999. Cambridge: The MIT Press, forthcoming 2000.

Hoshi, Takeo; Kashyap, Anil and Scharfstein, David. "The Role of Banks in Reducing the Costs of Financial Distress in Japan.” Journal of Financial Economics, September 1990, 27(1), pp. 67-88.

. "Corporate Structure, Liquidity, and Investment: Evidence from Japanese Industrial Groups.” Quarterly Journal of Economics, February 1991, 106(1), pp. 33-60.

Hoshi, Takeo; Scharfstein, David and Singleton, Kenneth J. “Japanese Corporate Investment and Bank of Japan Guidance of Commercial Bank Lending," in Kenneth J. Singleton, ed., Japanese Monetary Policy. Chicago, IL: University of Chicago Press, 1993.

Kashyap, Anil; Lamont, Owen A. and Stein, Jeremy C. "Credit Conditions and the Cyclical Behavior of Inventories." The Quarterly Journal of Economics, August 1994, pp. $565-92$.

Kashyap, Anil K. and Stein, Jeremy C. “The Impact of Monetary Policy on Bank Balance Sheets." Carnegie-Rochester Series on Public Policy, 1995, 42, pp. 151-95. . "Monetary Policy and Bank Lending," in N. Gregory Mankiw, ed., Monetary Policy. Chicago: University of Chicago Press, 1994, pp. 221-56. 
. "What Do a Million Observations on Banks Say About the Transmission of Monetary

Policy?" The American Economic Review, June 2000, 90, pp. 407-28.

Kashyap, Anil; Stein, Jeremy C. and Wilcox, David W. "Monetary Policy and Credit

Conditions: Evidence from the Composition of External Finance." American Economic



Klein, Michael W. and Rosengren, Eric S. “The Real Exchange Rate and Foreign Direct Investment in the United States. Journal of International Economics, 1994, 36, pp. 373-89.

Kloeck, Teun. "OLS Estimation in a Model Where a Microvariable is Explained by Aggregates and Contemporaneous Disturbances are Equicorrelated.” Econometrica, January 1981, $\underline{49}(1)$, pp. 205-07.

McCauley, Robert N. and Yeaple, Stephen. "How Lower Japanese Asset Prices Affect Pacific Financial Markets.” FRBNY Quarterly Review, Spring 1994, pp. 19-33.

Morck, Randall and Nakamura, Masao. "Banks and Corporate Control in Japan." The Journal of Finance, 1999, 54 (1) pp. 319-40.

Moulton, Brent. "An Illustration of a Pitfall in Estimating the Effects of Aggregate Variables on Micro Units." The Review of Economics and Statistics, 1990, 72, pp. 334-38.

Peek, Joe and Rosengren, Eric S. "The International Transmission of Financial Shocks: The Case of Japan.” The American Economic Review, September 1997, 87(4), pp. 495-505. - "Collateral Damage: Effects of the Japanese Bank Crisis on Real Activity in the United States." The American Economic Review, March 2000, 90(1), pp. 30-45.

Petersen, Mitchell A. and Rajan, Raghuram G. "The Benefits of Lending Relationships: Evidence from Small Business Data.” Journal of Finance, March 1994, 49, pp. 3-38. 
Slemrod, J. "Tax Effects on Foreign Direct Investment in the U.S.: Evidence from a CrossCountry Comparison." NBER Working paper no. 3042, 1989.

Swenson, D. "The Impact of U.S. Tax Reform on Foreign Investment in the United States." Journal of Public Economics, June 1994, 54(2) pp. 13-47.

Zeile, William J. "Foreign Direct Investment in the United States." Survey of Current Business, August 1999, pp. 21-54. 


\section{Footnotes}

1. Blonigen (1997) noted a second empirical observation concerning the correlation between FDI and the real exchange rate, that FDI was concentrated in industries with firm-specific assets, such as high technology firms. Rather than assuming imperfect capital markets, he assumed imperfect goods markets. If goods markets were segmented, with U.S. firms having limited access to foreign markets, foreign firms will value more highly firm-specific assets in the United States that can be extended to their operations abroad. He shows that the association between FDI and exchange rates is particularly strong for explaining Japanese FDI, where the goods markets may be segmented and where the acquisitions have been focused on firms in high technology. As with Froot and Stein (1991), Blonigen (1997) is able to provide a mechanism for motivating the link between real exchange rates and FDI with a stylized model that assumes that firms have equal access to credit markets.

2. The ITA data differ from the data collected by the BEA because the BEA data are based on a confidential survey, while the ITA data use publicly available information. However, the two series are highly correlated. Klein and Rosengren (1994) find an 86 percent correlation between total BEA outlays and total FDI as reported by the ITA.

3. Gibson (1995) has shown that virtually the same primary lender-borrower relationships are obtained using the first listed reference bank from the $\mathrm{JCH}$, the bank with the largest equity shareholding in the firm, or the bank with an employee on the firm's board of directors. The Japan Development Bank and Norinchukin Bank (The Central Co-operative Bank for Agriculture, Forestry, and Fisheries) are not considered to be main banks. In the few instances in which they are listed as the first reference bank, we used the first listed non-governmental bank. 
4. Sakura was created from the merger of Mitsui Bank and Taiyo Kobe Bank in 1990. No firms engaging in FDI were associated with Taiyo Kobe Bank and we treat Sakura as a continuation of Mitsui, consistent with the reference numbers in the JCH. Likewise, Asahi Bank was the result of the merger of Kyowa Bank and Saitama Bank in 1991. Following the treatment in the JCH, we treat Asahi as a continuation of Kyowa.

5. We use Moody's long-term deposit ratings. All of the rating changes during our sample period (from 1987 to 1994) were downgrades. Using an independent assessment of bank financial health, such as the Moody's ratings, is preferable to financial ratios based on balance sheet and income statements reported by the banks, given the well-known lack of accounting transparency in Japan.

6. Some specifications use the proportional change rather than the percentage change. We calculate the proportional change giving equal weight to the beginning and ending values of the level of FDI in the denominator: $\mathrm{DFDI}_{\mathrm{i}, \mathrm{t}}=\mathrm{FDI}_{\mathrm{i}, \mathrm{t}}-\mathrm{FDI}_{\mathrm{i}, \mathrm{t}-1} / 0.5\left(\mathrm{FDI}_{\mathrm{i}, \mathrm{t}}+\mathrm{FDI}_{\mathrm{i}, \mathrm{t}-1}\right)$, where $\mathrm{FDI}_{\mathrm{i}, \mathrm{t}}$ is the number of investments by firms associated with bank $i$ in year $t$. We use this formulation instead of giving all weight to the beginning-of-period value because the number of firms engaging in FDI for some banks is zero for some years when we consider subsets of our sample of firms. In specifications that use the proportional change formulation for the dependent variable, we also use the proportional change rather than the percentage change for the relative wealth measure, as described below.

7. Diawa Bank is the only instance in which a bank is downgraded by more than two levels in a single year. It declines by three levels in 1993.

8. A second measure of firm health, Firm Market Value, was included in some specifications. It is calculated for each main bank as the percent change in an index of the sum of market values at the end of the prior year of all firms associated with that bank, deflated by the Japanese wholesale price index. However, we do not report the results for this variable. It did not affect the results for the ratings 
downgrade variables and it tended to be correlated with the relative wealth and profitability variables. We do include firm market value in the next section, where we investigate the determinants of the probability that individual firms engage in foreign direct investment.

9. The use of aggregate regressors, represented by DMACRO, suggests a likely correlation among regression errors within a particular year. Failure to account for within-year correlation when computing coefficient standard errors would result in incorrect t-statistics (Kloeck 1981; Moulton 1990). We compute robust standard errors allowing for dependence of regression errors within years to adjust for this bias.

10. We have eight years of ITA data that provide seven observations per bank for the change in FDI. We lose four observations at the beginning of the sample because some banks did not yet have a Moody's rating.

11. We estimate a fixed-effects logit for panel data models following Chamberlain (1980). The eight industry groupings, based on the Japan Company Handbook classifications, are extraction, nondurables, durables, trade, finance, real estate, transport, and miscellaneous. 


\section{Figure 1}

\section{Japanese Foreign Direct Investment into the United States}

and the Relative Exchange Rate

40

35

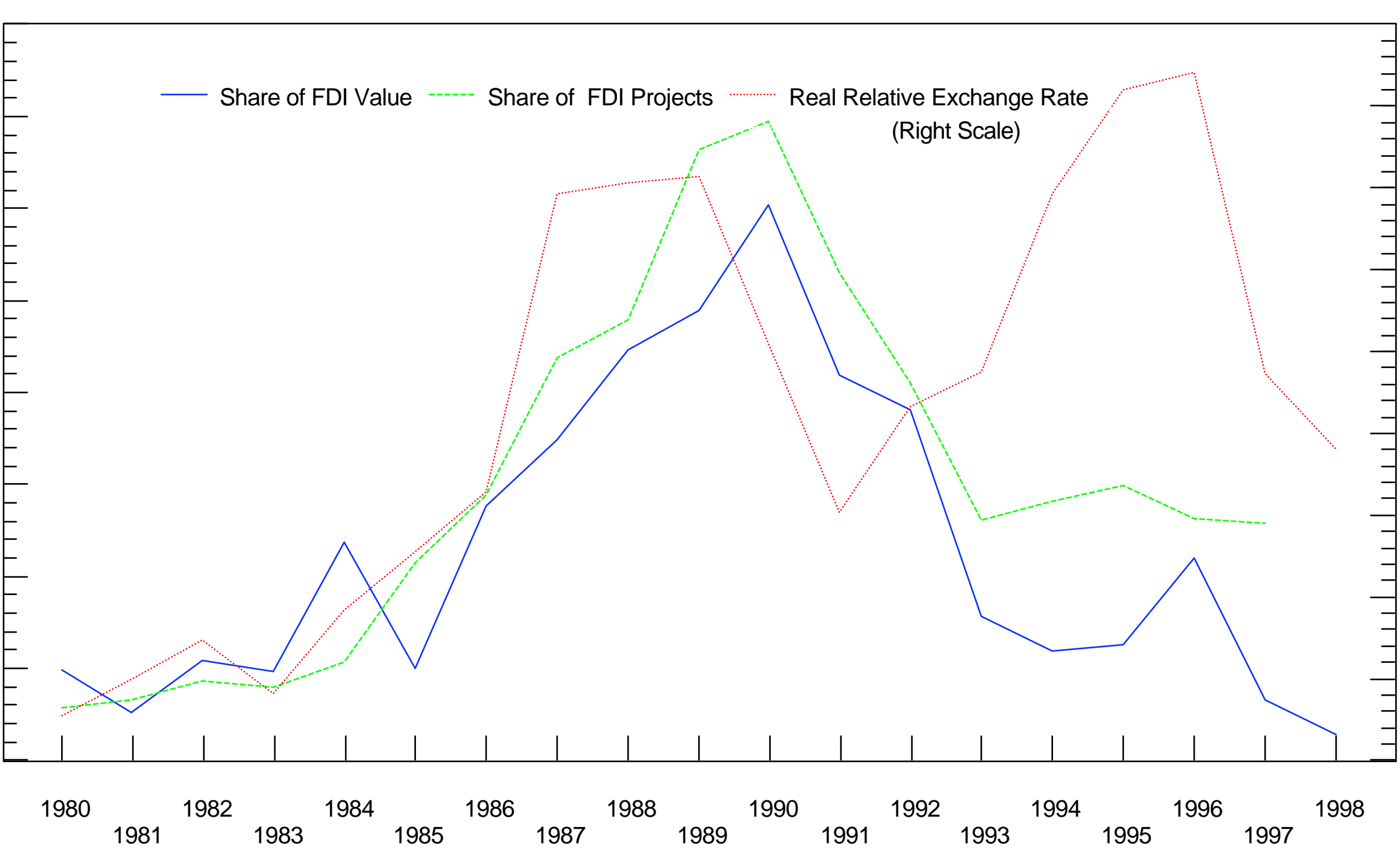

30

1.40 


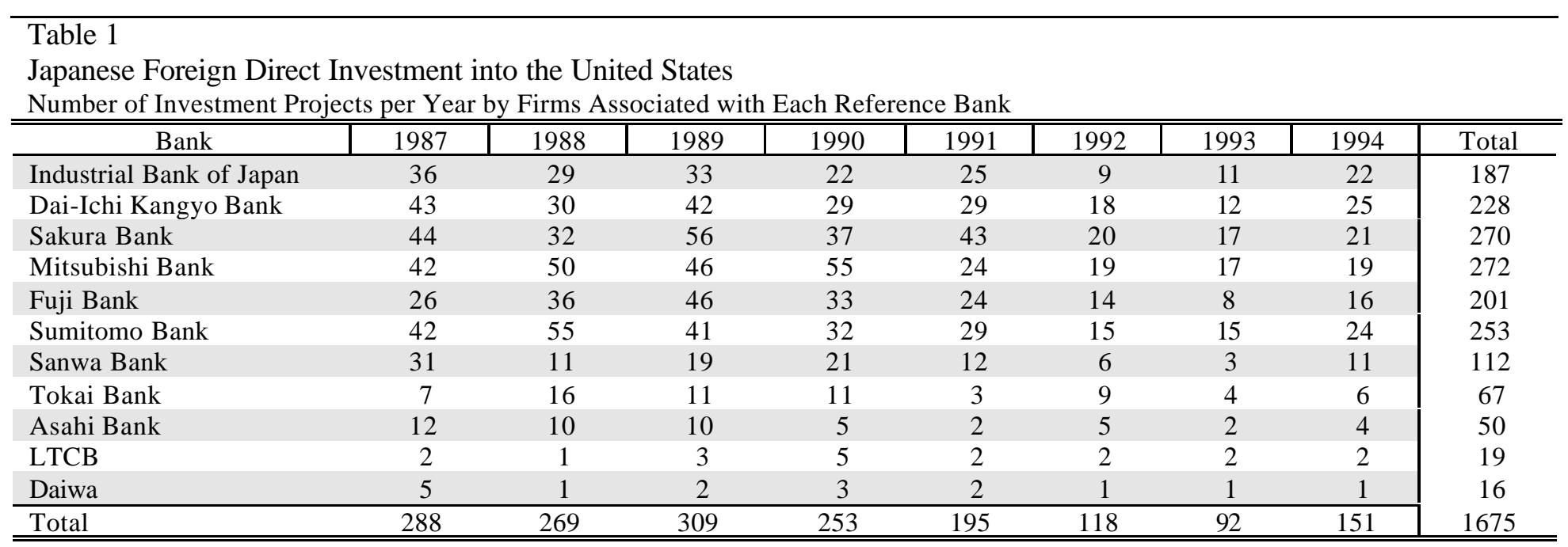




\begin{tabular}{|c|c|c|c|c|c|c|c|c|c|}
\hline \multicolumn{10}{|c|}{$\begin{array}{l}\text { Table } 2 \\
\text { Moody's Long-Term Deposit Ratings } \\
\text { Rating as of December } 31\end{array}$} \\
\hline Bank & 1986 & 1987 & 1988 & 1989 & 1990 & 1991 & 1992 & 1993 & 1994 \\
\hline Industrial Bank of Japan & Aaa & Aaa & Aaa & Aaа & Aaa & Aa2 & Aa3 & Aa3 & A1 \\
\hline Dai-Ichi Kangyo Bank & Aaa & Aaa & Aaa & Aaa & Aa1 & Aa1 & A a3 & $\mathbf{A 1}$ & A1 \\
\hline Sakura Bank & N/A & N/A & $\mathrm{Aa} 2$ & Aa3 & Aa3 & A1 & A 1 & A2 & A2 \\
\hline Mitsubishi Bank & Aaa & Aaa & Aaa & Aaa & Aa1 & Aa1 & A a3 & Aa3 & Aa3 \\
\hline Fuji Bank & Aaa & Aaa & Aaа & Aaа & Aa1 & A a3 & Aa3 & A1 & A1 \\
\hline Sumitomo Bank & Aaa & Aaa & Aaa & Aaa & Aa1 & A a3 & Aa3 & A1 & A1 \\
\hline Sanwa Bank & Aaa & Aa1 & Aa1 & Aa1 & Aal & Aa1 & A a3 & Aa3 & $\mathrm{Aa} 3$ \\
\hline Tokai Bank & N/A & $\mathrm{Aa} 2$ & $\mathrm{Aa} 2$ & $\mathrm{Aa} 2$ & Aa3 & Aa3 & A1 & $\mathbf{A 2}$ & $\mathrm{A} 2$ \\
\hline Asahi Bank & N/A & N/A & Aa3 & Aa3 & Aa3 & $\mathrm{Aa} 3$ & A1 & A2 & $\mathrm{A} 2$ \\
\hline LTCB & Aaa & A a2 & $\mathrm{Aa} 2$ & $\mathrm{Aa} 2$ & $\mathbf{A} 1$ & A2 & $\mathrm{A} 2$ & A3 & A3 \\
\hline Daiwa & N/A & N/A & N/A & Aa3 & Aa3 & Aa3 & Aa3 & A3 & A3 \\
\hline
\end{tabular}

The ordering of these ratings, from best to worst, is as follows: Aaa, Aa1, Aa2, Aa3, A1, A2, A3.

Bold figures indicate the bank's rating fell by one level in that year. The italicized figures indicate the bank's rating fell

by more than one level. 


\begin{tabular}{|c|c|c|c|c|}
\hline \multicolumn{5}{|c|}{$\begin{array}{l}\text { Table } 3 \\
\text { Determinants of the Change in the Number of Japanese FDI Projects }\end{array}$} \\
\hline & \multicolumn{2}{|c|}{ All FDI Firms } & \multicolumn{2}{|c|}{ Multiple-Year FDI Firms } \\
\hline & $\begin{array}{c}\text { Percentage Change } \\
11 \text { Banks } \\
\end{array}$ & $\begin{array}{c}\text { Proportional Change } \\
11 \text { Banks }\end{array}$ & $\begin{array}{c}\text { Proportional Change } \\
11 \text { Banks }\end{array}$ & $\begin{array}{c}\text { Proportional Change } \\
9 \text { Banks } \\
\end{array}$ \\
\hline Single Downgrade $_{t-1}$ & $\begin{array}{l}-31.06^{* * *} \\
(2.93)\end{array}$ & $\begin{array}{c}-28.94 * * \\
(2.99)\end{array}$ & $\begin{array}{c}-37.38 * * \\
(3.18)\end{array}$ & $\begin{array}{r}-34.45^{*} \\
(2.03)\end{array}$ \\
\hline Multiple Downgrades $_{\mathrm{t}-1}$ & $\begin{array}{c}-65.09 * * \\
(3.33)\end{array}$ & $\begin{array}{c}-57.76^{* *} \\
(4.27)\end{array}$ & $\begin{array}{c}-85.38 * * \\
(3.23)\end{array}$ & $\begin{array}{c}-64.35 * * \\
(3.84)\end{array}$ \\
\hline Relative Wealth $_{\mathrm{t}-1}$ & $\begin{array}{c}.83 \\
(1.62)\end{array}$ & $\begin{array}{c}.49 \\
(1.37)\end{array}$ & $\begin{array}{c}.48 \\
(1.72)\end{array}$ & $\begin{array}{r}.87 * \\
(2.33)\end{array}$ \\
\hline Firm Profitability $t-1$ & $\begin{array}{l}-3.83 \\
(0.30)\end{array}$ & $\begin{array}{c}5.24 \\
(0.39)\end{array}$ & $\begin{array}{l}14.40 * * \\
(2.86)\end{array}$ & $\begin{array}{l}21.20 \\
(1.10)\end{array}$ \\
\hline U.S. Unemployment Rate ${ }_{t-1}$ & $\begin{array}{r}-14.01 \\
(0.77)\end{array}$ & $\begin{array}{c}-24.30 * \\
(2.08)\end{array}$ & $\begin{array}{c}-14.99 * \\
(2.21)\end{array}$ & $\begin{array}{r}-11.92 \\
(1.01)\end{array}$ \\
\hline $\begin{array}{l}\text { (Japan Job Offers/ } \\
\text { Applications) } t-1\end{array}$ & $\begin{array}{r}-111.34^{*} \\
(2.54)\end{array}$ & $\begin{array}{c}-92.33 * * \\
(3.61)\end{array}$ & $\begin{array}{c}-102.09 * * \\
(6.14)\end{array}$ & $\begin{array}{c}-119.77 * * \\
(4.51)\end{array}$ \\
\hline Constant & $\begin{array}{l}30.37 \\
(1.61) \\
\end{array}$ & $\begin{array}{r}5.79 \\
(0.38) \\
\end{array}$ & $\begin{array}{r}1.40 \\
(0.19) \\
\end{array}$ & $\begin{array}{l}-6.16 \\
(0.27) \\
\end{array}$ \\
\hline $\mathrm{n}$ & 73 & 73 & 73 & 61 \\
\hline $\mathrm{R}^{2}$ & .277 & .361 & .246 & .340 \\
\hline Root MSE & .597 & .443 & .624 & .495 \\
\hline
\end{tabular}

Notes: Firm profitability is calculated as the change in the sum of profits for the set of firms associated with each bank, scaled by the sum of their assets. The estimated coefficients have been multiplied by $10^{6}$ for purposes of presentation. Relative wealth is measured as the percentage change in the real Nikkei index, using the wholesale price index as the deflator, plus the real (dollar/yen) exchange rate, minus the percentage change in the real S\&P500 index, using the producer price index as the deflator. The U.S. unemployment rate and the Japanese joboffers-to-applications ratio are in first-difference form. Daiwa and LTCB are omitted from the sample for the regression reported in column 4. Below each estimated coefficient, we report the associated absolute value of the t-statistic based on the robust standard error calculated by relaxing the assumption of independence of the observations for a given year.

* Significant at the 5 percent level. ** Significant at the 1 percent level. 


\begin{tabular}{|c|c|c|c|}
\hline \multicolumn{4}{|c|}{$\begin{array}{l}\text { Table } 4 \\
\text { Determinants of Japanese FDI for Individual Firms } \\
\text { Multiple Year FDI Firms; Estimation Method: Logit }\end{array}$} \\
\hline & Ratings Only & Full Specification & Non Autos, Non Steel \\
\hline AA1 & $\begin{array}{l}-.671 * * \\
(3.17)\end{array}$ & $\begin{array}{c}-.359 \\
(1.58)\end{array}$ & $\begin{array}{r}-.391 \\
(1.40)\end{array}$ \\
\hline AA2 & $\begin{array}{c}-.206 \\
(0.69)\end{array}$ & $\begin{array}{l}-.062 \\
(0.30)\end{array}$ & $\begin{array}{r}.007 \\
(0.03)\end{array}$ \\
\hline AA3 & $\begin{array}{l}-1.098 * * \\
(6.53)\end{array}$ & $\begin{array}{l}-.593 * * \\
(3.04)\end{array}$ & $\begin{array}{l}-.753 * * \\
(3.36)\end{array}$ \\
\hline $\mathrm{A} 1$ & $\begin{array}{l}-.775^{* *} \\
(3.80)\end{array}$ & $\begin{array}{c}-.321 \\
(1.70)\end{array}$ & $\begin{array}{c}-.426 \\
(1.94)\end{array}$ \\
\hline $\mathrm{A} 2$ & $\begin{array}{l}-1.202 * * \\
(8.25)\end{array}$ & $\begin{array}{l}-.884 * * \\
(3.12)\end{array}$ & $\begin{array}{l}-.923 * * \\
(3.04)\end{array}$ \\
\hline $\mathrm{A} 3$ & $\begin{array}{l}-2.175^{* *} \\
(21.84)\end{array}$ & $\begin{array}{l}-1.738^{* *} \\
(9.37)\end{array}$ & $\begin{array}{l}-1.742 * * \\
(7.83)\end{array}$ \\
\hline Relative Wealth $_{\mathrm{t}-1}$ & & $\begin{array}{l}.219^{*} \\
(2.18)\end{array}$ & $\begin{array}{r}.250 \\
(1.77)\end{array}$ \\
\hline Firm Profitability t-1 & & $\begin{array}{l}2.539 * * \\
(3.09)\end{array}$ & $\begin{array}{l}1.963^{*} \\
(2.56)\end{array}$ \\
\hline Firm Size $_{t-1}$ & & $\begin{array}{l}.451^{* *} \\
(8.56)\end{array}$ & $\begin{array}{l}.426 * * \\
(6.40)\end{array}$ \\
\hline U.S. Unemployment Rate ${ }_{t-1}$ & & $\begin{array}{l}-.484 * * \\
(6.41)\end{array}$ & $\begin{array}{l}-.435^{* *} \\
(4.14)\end{array}$ \\
\hline (Japan Job Offers/Applications) $_{t-1}$ & & $\begin{array}{l}-.892 * * \\
(3.35)\end{array}$ & $\begin{array}{l}-.734^{*} \\
(2.34)\end{array}$ \\
\hline Constant & $\begin{array}{l}.229 * \\
(2.30) \\
\end{array}$ & $\begin{array}{r}.873 \\
(0.78) \\
\end{array}$ & $\begin{array}{l}1.082 \\
(0.65) \\
\end{array}$ \\
\hline $\mathrm{n}$ & 1484 & 1484 & 1303 \\
\hline Pseudo $\mathrm{R}^{2}$ & .037 & .110 & .107 \\
\hline Log Likelihood & -965.4 & -892.1 & -780.2 \\
\hline
\end{tabular}

Notes: Relative wealth is calculated as the logarithm of: the firm's market value (indexed to 1992) multiplied by the (yen/dollar) exchange rate, divided by the S\&P 500 index. Firm profitability is measured as the firm's profits-to-assets ratio. Firm size is measured as the logarithm of the real value of the firm's assets, using the Japanese wholesale price index as the deflator. The specifications in columns 2 and 3 also include a set of dummy variables for eight industry groupings. Below each estimated coefficient, we report the associated absolute value of the t-statistic based on the robust standard error calculated by relaxing the assumption of independence of the observations for a given year.

* Significant at the 5 percent level. ** Significant at the 1 percent level. 


\begin{tabular}{|c|c|c|c|}
\hline \multicolumn{4}{|c|}{$\begin{array}{l}\text { Table } 5 \\
\text { Determinants of Japanese FDI for Individual Firms } \\
\text { Multiple Year FDI Firms; Estimation Method: Logit } \\
\end{array}$} \\
\hline & $\begin{array}{c}\text { Excluding } \\
\text { Largest Firms }\end{array}$ & $\begin{array}{l}\text { Excluding New York } \\
\text { or London Listed }\end{array}$ & $\begin{array}{c}\text { Excluding Firms with } \\
\text { Largest Bonds/Liabilities }\end{array}$ \\
\hline AA1 & $\begin{array}{l}-.505^{*} \\
(2.00)\end{array}$ & $\begin{array}{c}-.422^{*} \\
(2.01)\end{array}$ & $\begin{array}{r}-.378 \\
(1.38)\end{array}$ \\
\hline AA2 & $\begin{array}{c}-.008 \\
(0.06)\end{array}$ & $\begin{array}{l}-.036 \\
(0.24)\end{array}$ & $\begin{array}{c}-.160 \\
(0.52)\end{array}$ \\
\hline AA3 & $\begin{array}{l}-.606^{* *} \\
(3.52)\end{array}$ & $\begin{array}{l}-.592 * * \\
(2.96)\end{array}$ & $\begin{array}{l}-.615^{*} \\
(2.38)\end{array}$ \\
\hline A1 & $\begin{array}{l}-.402 * \\
(2.23)\end{array}$ & $\begin{array}{l}-.229 \\
(1.15)\end{array}$ & $\begin{array}{l}-.308 \\
(1.24)\end{array}$ \\
\hline $\mathrm{A} 2$ & $\begin{array}{l}-.834 * * \\
(3.06)\end{array}$ & $\begin{array}{l}-.774 * * \\
(2.72)\end{array}$ & $\begin{array}{l}-1.043 * \\
(2.36)\end{array}$ \\
\hline $\mathrm{A} 3$ & $\begin{array}{l}-1.751 * * \\
(10.10)\end{array}$ & $\begin{array}{l}-1.684 * * \\
(8.83)\end{array}$ & $\begin{array}{l}-1.193 * * \\
(4.66)\end{array}$ \\
\hline Relative Wealth $t-1$ & $\begin{aligned} .170 \\
(1.64)\end{aligned}$ & $\begin{array}{l}.286^{* *} \\
(3.12)\end{array}$ & $\begin{array}{r}.290 \\
(1.45)\end{array}$ \\
\hline Firm Profitability $\mathrm{t}-1$ & $\begin{array}{l}2.693 * * \\
(2.85)\end{array}$ & $\begin{array}{l}2.594 * * \\
(2.93)\end{array}$ & $\begin{array}{l}3.596 * * \\
(2.85)\end{array}$ \\
\hline Firm Size $_{t-1}$ & $\begin{array}{l}.396 * * \\
(7.11)\end{array}$ & $\begin{array}{l}.424 * * \\
(10.35)\end{array}$ & $\begin{array}{l}.488 * * \\
(7.83)\end{array}$ \\
\hline U.S. Unemployment Rate ${ }_{\mathrm{t}-1}$ & $\begin{array}{l}-.372 * * \\
(5.25)\end{array}$ & $\begin{array}{l}-.431 * * \\
(5.82)\end{array}$ & $\begin{array}{l}-.432 * * \\
(4.68)\end{array}$ \\
\hline (Japan Job Offers/Applications) $_{\mathrm{t}-1}$ & $\begin{array}{l}-.737 * * \\
(2.85)\end{array}$ & $\begin{array}{l}-.855^{* *} \\
(2.90)\end{array}$ & $\begin{array}{l}-.785^{*} \\
(2.32)\end{array}$ \\
\hline Constant & $\begin{array}{l}.164 \\
(0.18)\end{array}$ & $\begin{array}{l}1.526 \\
(1.74)\end{array}$ & $\begin{array}{r}.691 \\
(0.35)\end{array}$ \\
\hline $\mathrm{n}$ & 1206 & 1371 & 1336 \\
\hline Pseudo $\mathrm{R}^{2}$ & .069 & .100 & .117 \\
\hline Log Likelihood & -731.4 & -822.5 & -800.1 \\
\hline
\end{tabular}

Notes: Relative wealth is calculated as the logarithm of: the firm's market value (indexed to 1992) multiplied by the (yen/dollar) exchange rate, divided by the S\&P 500 index. Firm profitability is measured as the firm's profits-to-assets ratio. Firm size is measured as the logarithm of the real value of the firm's assets, using the Japanese wholesale price index as the deflator. Column 1 excludes those firms that were among the largest (measured by assets) 10 percent of firms in any year. Column 2 excludes any firms that were listed on the New York or London (or both) stock exchanges at any time during our sample period. Column 3 excludes the 10 percent of the firms with the largest ratio of bonds to total liabilities. Each specification also includes a set of dummy variables for eight industry groupings. Below each estimated coefficient, we report the associated absolute value of the t-statistic based on the robust standard error calculated by relaxing the assumption of independence of the observations for a given year.

* Significant at the 5 percent level.

** Significant at the 1 percent level. 
Federal Reserve Bank of Boston - Working Papers

1991 Series

No. 1 "Why State Medicaid Costs Vary: A First Look," by Jane Sneddon Little.

No. 2 "Are Pensions Worth the Cost?" by Alicia H. Munnell. In National Tax Journal, Proceedings of the National Tax Association- -Tax Institute of America Symposium "Tax Policy: New Perspectives," May 9 - 10, 1991, vol. XLIV, no. 3 (September 1991), pp. 393-403.

No. 3 "The Capitalization and Portfolio Risk of Insurance Companies," by Richard W. Kopcke.

No. 4 "The Capital Crunch: Neither a Borrower Nor a Lender Be," by Joe Peek and Eric Rosengren. Journal of Money, Credit and Banking, vol. 27, no. 3, August 1995, pp. 625-38.

No. 5 "What Is the Impact of Pensions on Saving? The Need for Good Data," by Alicia H. Munnell and Frederick O. Yohn. In Pensions and the Economy: Sources, Uses, and Limitations of Data, Zvi Bodie and Alicia H. Munnell, eds. University of Pennsylvania Press for the Pension Research Council, 1992.

No. 6 "Treasury Bill Rates in the 1970s and 1980s," by Patric H. Hendershott and Joe Peek. Revision published in Journal of Money, Credit and Banking, vol. 24, May 1992, pp. 195-214.

No. 7 "The Measurement and Determinants of Single-Family House Prices," by Joe Peek and James A. Wilcox. Revision published in Journal of the American Real Estate and Urban Economics Association, vol. 19, no. 3, Fall 1991, pp. 353-82.

No. 8 "Economic Rents, the Demand for Capital, and Financial Structure," by Richard W. Kopcke. 1992 Series -

No. 1 - "Back to the Future: Monetary Policy and the Twin Deficits," by Geoffrey M.B. Tootell.

No. 2 - "The Real Exchange Rate and Foreign Direct Investment in the United States: Relative Wealth vs. Relative Wage Effects," by Michael W. Klein and Eric Rosengren. Revision published in Journal of International Economics, vol. 36, no. 3/4, May 1994, pp. 373-90.

No. 3 - "Tobin's q, Economic Rents, and the Optimal Stock of Capital," by Richard W. Kopcke.

No. 4 - "The Role of Real Estate in the New England Credit Crunch," by Joe Peek and Eric S. Rosengren. Published as "Bank Real Estate Lending and the New England Capital Crunch," AREUEA, Winter 1994, vol. 22, no. 1, pp. 33-58. 
No. 5 - "Failed Bank Resolution and the Collateral Crunch: The Advantages of Adopting Transferable

Puts," by Eric S. Rosengren and Katerina Simons. AREUEA, Spring 1994, vol. 22, no. 1, pp. 135-47.

No. 6 - "Defaults of Original Issue High-Yield Bonds," by Eric S. Rosengren. Revision published in Journal of Finance, vol. 48, no. 1, March 1993, pp. 345-62.

No. 7 - "Mortgage Lending in Boston: Interpreting HMDA Data," by Alicia H. Munnell, Lynn E. Browne, James McEneaney, and Geoffrey M.B. Tootell. Revision published in The American Economic Review, vol. 86, no. 1, March 1996, pp. 25-53.

1993 Series

No. 1 - "Assessing the Performance of Real Estate Auctions," by Christopher J. Mayer.

No. 2 - "Bank Regulation and the Credit Crunch," by Joe Peek and Eric Rosengren. Journal of Banking and Finance, vol. 19, no. 1, June 1995, pp. 769-92.

No. 3 - "A Model of Real Estate Auctions versus Negotiated Sales," by Christopher J. Mayer. Journal of Urban Economics, vol. 38, July 1995, pp. 1-22.

No. 4 - "Empirical Evidence on Vertical Foreclosure," by Eric S. Rosengren and James W. Meehan, Jr. Economic Inquiry, vol. 32, no. 2, April 1994, pp. 303-17.

No. 5 - "Reverse Mortgages and the Liquidity of Housing Wealth," by Christopher J. Mayer and

Katerina V. Simons. AREUEA, Summer 1994, vol. 22, no. 2, pp. 235-55.

No. 6 - "Equity and Time to Sale in the Real Estate Market," by David Genesove and Christopher J. Mayer. The American Economic Review, vol. 87, no. 3, June 1997, pp. 255-69.

1994 Series

No. 1 - "Monetary Policy When Interest Rates Are Bounded at Zero," by Jeffrey Fuhrer and Brian Madigan. The Review of Economics and Statistics, vol. 79, November 1997, pp. 573-85.

No. 2 - "Optimal Monetary Policy in a Model of Overlapping Price Contracts," by Jeffrey C. Fuhrer. Published as Anflation/Output Variance Trade-offs and Optimal Monetary Policy,@Journal of Money, Credit and Banking, vol. 29, no. 2, May 1997, pp. 214-34.

No. 3 - "Near Common Factors and Confidence Regions for Present Value Models," by Stephen R. Blough.

No. 4 - "Estimating Revenues from Tax Reform in Transition Economies," by Yolanda K. Kodrzycki. In Tax Modeling for Economies in Transition. OECD:Macmillan, 1998. 
No. 5 - "Gifts, Down Payments, and Housing Affordability," by Christopher J. Mayer and Gary V. Engelhardt. Journal of Housing Research, Summer 1996.

No. 6 - "Near Observational Equivalence and Persistence in GNP," by Stephen R. Blough.

1995 Series

No. 1 - "Banks and the Availability of Small Business Loans," by Joe Peek and Eric S. Rosengren.

No. 2 - "Bank Regulatory Agreements and Real Estate Lending," by Joe Peek and Eric S. Rosengren. Real Estate Economics, vol. 24, No. 1, Spring 1996, pp. 55-73.

No. 3 - "Housing Price Dynamics within a Metropolitan Area," by Karl E. Case and Christopher J. Mayer. Regional Science and Urban Economics, vol. 26, nos. 3-4, June 1996, pp. 387-407.

No. 4 - "Tobin's q, Economic Rents, and the Optimal Stock of Capital," by Richard W. Kopcke.

No. 5 - "Small Business Credit Availability: How Important Is Size of Lender?" by Joe Peek and Eric S. Rosengren. In A. Saunders and I. Walter, eds., Universal Banking Financial System Design Reconsidered, 1996, pp. 628-55. Homewood, IL: Irwin Professional Publishing.

No. 6 - "The (Un)Importance of Forward-Looking Behavior in Price Specifications," by Jeffrey C. Fuhrer. Journal of Money, Credit and Banking, vol. 29, no. 3, pp. 338-50, August 1997.

No. 7 - "Modeling Long-Term Nominal Interest Rates: The Pure Expectations Hypothesis and Changing Expectations of Monetary Policy Behavior," by Jeffrey C. Fuhrer. Published as AMonetary Policy Shifts and Long-Term Interest Rates," Quarterly Journal of Economics, no. 111, November 1996, pp. 1183-1209.

No. 8 - "Debt Capacity, Tax-Exemption, and the Municipal Cost of Capital: A Reassessment of the New View," by Peter Fortune. See Working Paper 96-9, which supersedes it.

No. 9 - "Estimating Demand Elasticities in a Differentiated Product Industry: The Personal Computer Market," by Joanna Stavins. Journal of Economics and Business, July/August 1997.

No. 10- "Discrimination, Redlining, and Private Mortgage Insurance," by Geoffrey M.B. Tootell.

No. 11- "Intergenerational Transfers, Borrowing Constraints, and Saving Behavior: Evidence from the Housing Market," by Gary V. Englehardt and Christopher J. Mayer.

No. 12- "A New Approach to Causality and Economic Growth," by Steven M. Sheffrin and Robert K. Triest. 
1996 Series

No. 1 - "The International Transmission of Financial Shocks," by Joe Peek and Eric S. Rosengren. Revision in The American Economic Review, vol. 87, no. 4 (September) 1997, pp. 495-505.

No. 2 - AComputationally Efficient Solution and Maximum Likelihood Estimation of Nonlinear Rational Expectations Models," by Jeffrey C. Fuhrer and C. Hoyt Bleakley.

No. 3 - ADerivatives Activity at Troubled Banks," by Joe Peek and Eric S. Rosengren. Journal of Financial Services Research, vol. 12, no. 2/3 (October/December) 1997, pp. 287-302.

No. 4 - AThe Maturity Structure of Term Premia with Time-Varying Expected Returns," by Mark A. Hooker.

No. 5 - AWill Legislated Early Intervention Prevent the Next Banking Crisis?" by Joe Peek and Eric S. Rosengren. Southern Economic Journal, July 1997, pp. 268-80.

No. 6 - ARedlining in Boston: Do Mortgage Lenders Discriminate Against Neighborhoods?" by Geoffrey M.B. Tootell. Quarterly Journal of Economics, November 1996.

No. 7 - Arice Discrimination in the Airline Market: The Effect of Market Concentration," by Joanna Stavins. Forthcoming, The Review of Economics and Statistics.

No. 8 - ATowards a Compact, Empirically Verified Rational Expectations Model for Monetary Policy Analysis," by Jeffrey C. Fuhrer. Carnegie-Rochester Conference Series on Public Policy, 47

(December 1997), pp. 197-230.

No. 9 - ATax-Exempt Bonds Really Do Subsidize Municipal Capital!" by Peter Fortune. National Tax Journal, March 1998.

No.10- ACan Studies of Application Denials and Mortgage Defaults Uncover Taste-Based Discrimination?" by Geoffrey M.B. Tootell.

No.11- AReserve Banks, the Discount Rate Recommendation, and FOMC Policy," by Geoffrey M.B. Tootell. Southern Economic Journal, vol. 66 (4), March 2000, pp. 957-75.

No.12- AUnifying Empirical and Theoretical Models of Housing Supply," by Christopher J. Mayer and C. Tsuriel Somerville.

1997 Series

No. 1 - ABank Consolidation and Small Business Lending: It Not Just Size That Matters,” by Joe 
Peek and Eric S. Rosengren. Journal of Banking and Finance, vol. 22, nos. 6-8 (August 1998), pp. 799-820.

No. 2 - AProperty Tax Limits and Local Fiscal Behavior: Did Massachusetts Cities and Towns Spend Too Little on Town Services under Proposition 2 1/2? @by Katharine L. Bradbury, Christopher L. Mayer, and Karl E. Case. Forthcoming, Journal of Public Economics, as "Property Tax Limits, Local Fiscal Behavior, and Property Values: Evidence from Massachusetts under Proposition 2 1/2."

No. 3 - As Bank Supervision Central to Central Banking?" by Joe Peek, Eric S. Rosengren, and Geoffrey M. B. Tootell. See revised version, 98-2.

No. 4 - AManagers=Opportunistic Trading of Their Firms=Shares: A Case Study of Executives in the Banking Industry," by John S. Jordan. Revision forthcoming as "Bankers' Opportunistic Trading of Their Firms' Shares," Journal of Financial Management, Winter 1999.

No. 5 - ACollateral Damage: Effects of the Japanese Real Estate Collapse on Credit Availability and Real Activity in the United States," by Joe Peek and Eric S. Rosengren. The American Economic Review, March 2000.

No. 6 - AThe Effect of Pricing on Demand and Revenue in Federal Reserve ACH Payment Processing," by Joanna Stavins and Paul W. Bauer. Journal of Financial Services Research, September 1999, vol. 16, no. 1.

No. 7 - Anput and Output Inventories,” by Brad R. Humphreys, Louis J. Maccini, and Scott Schuh. Forthcoming, Journal of Monetary Economics.

No. 8 - AThe Subsidy from State and Local Tax Deductibility: Trends, Methodological Issues, and Its Value after Federal Tax Reform," by Robert Tannenwald.

1998 Series

No. 1 - An Optimizing Model for Monetary Policy Analysis: Can Habit Formation Help?" by Jeffrey C. Fuhrer. Published as "Habit Formation in Consumption and Its Implications for Monetary Policy Models." The American Economic Review, vol. 90 (3), June 2000, pp. 367-90.

No. 2 - ADoes the Federal Reserve Have an Informational Advantage? You Can Bank on It," by Joe Peek, Eric S. Rosengren, and Geoffrey M. B. Tootell. (See also WP 97-3.) Substantially revised version appears in the Quarterly Journal of Economics, May 1999.

No. 3 - AThe Poor Performance of Foreign Bank Subsidiaries: Were the Problems Acquired or Created?" by Joe Peek, Eric S. Rosengren, and Faith Kasirye. Revision published in Journal of Banking and Finance, vol. 23, February 1999, pp. 579-604. 
No. 4 - AWhat Do Cross-Sectional Growth Regressions Tell Us about Convergence?" by Daniel G. Swaine.

No. 5 - ADynamic Inconsistencies: Counterfactual Implications of a Class of Rational Expectations Models," by Arturo Estrella and Jeffrey C. Fuhrer. October 1999 revised version is available on the Bank's web site www.bos.frb.org. Forthcoming, The American Economic Review, 2001.

No. 6 - AWeekends Can Be Rough? The Weekend Effect in Stock Prices," by Peter Fortune. Revised version appears in the New England Economic Review, September/October 1999.

No. 7 - Aapanese Banking Problems: Implications for Southeast Asia," by Joe Peek and Eric S. Rosengren. Forthcoming in the Journal of International Economics.

No. 8 - AWill Greater Disclosure and Transparency Prevent the Next Banking Crisis?" by Eric S. Rosengren. In William C. Hunter, George Kaufman, and Thomas Krueger, eds., The Asian Financial Crisis: Origins, Implications and Solutions. Kluwer Academic Publishers, 1999.

No. 9 - ADeterminants of the Japan Premium: Actions Speak Louder than Words," by Joe Peek and Eric S. Rosengren. Forthcoming, Journal of International Economics.

1999 Series

No. 1 - AThe Impact of Greater Bank Disclosure Amidst a Banking Crisis," by John S. Jordan, Joe Peek, and Eric S. Rosengren. Revised version, "The Market Reaction to the Disclosure of Supervisory Actions: Implications for Bank Transparency," forthcoming, Journal of Financial Intermediation.

No. 2 - Aroductivity Shocks, Investment, and the Real Interest Rate,’ by Giovanni Olivei.

No. 3 - AFiscal Retrenchments and the Level of Economic Activity," by Giovanni Olivei.

No. 4 - "Are Deep Parameters Stable? The Lucas Critique as an Empirical Hypothesis," by Arturo Estrella and Jeffrey C. Fuhrer. October 1999 revised version is available on the Bank's web site www.bos.frb.org.

No. 5 - "Network Externalities and Technology Adoption: Lessons from Electronic Payments," by Gautam Gowrisankaran and Joanna Stavins.

No. 6 - "Capital Account Liberalization, Financial Depth, and Economic Growth," by Michael Klein and Giovanni Olivei.

No. 7 - "Is Bank Supervision Central to Central Banking?" by Joe Peek, Eric S. Rosengren, and Geoffrey M. B. Tootell. Quarterly Journal of Economics, vol. 114, May 1999. 
No. 8 - "Does the Federal Reserve Possess an Exploitable Informational Advantage?" by Joe Peek, Eric S. Rosengren, and Geoffrey M. B. Tootell.

No. 9 - "Is the U.S. Economy Characterized by Endogenous Growth? A Time Series Test of Two Stochastic Growth Models," by Daniel G. Swaine.

No.10 - "Gross Job Flows and Firms," by Scott Schuh and Robert K. Triest. Proceedings of the American Statistical Association, Government Statistics Section, forthcoming.

No.11 - "Job Creation, Job Destruction, and the Real Exchange Rate," by Michael W. Klein, Scott Schuh, and Robert K. Triest.

\section{Series}

No. 1 - "Monetary Policy, Housing Investment, and Heterogeneous Regional Markets," by Michael Fratantoni and Scott Schuh.

No. 2 - "Identifying the Macroeconomic Effect of Loan Supply Shocks," by Joe Peek, Eric S. Rosengren, and Geoffrey M.B. Tootell.

No. 3 - “Deposit Insurance, Capital Requirements, and Financial Stability,” by Richard W. Kopcke.

No. 4 - "Troubled Banks, Impaired Foreign Direct Investment: The Role of Relative Access to Credit," by Michael W. Klein, Joe Peek, and Eric S. Rosengren 